\title{
HUBUNGAN PEMBERIAN PENGHARGAAN (REWARD) DENGAN KINERJA PETUGAS REKAM MEDIS DI RSUP H.ADAM MALIK MEDAN TAHUN 2017
}

\author{
${ }^{1 .}$ Marta Simanjuntak; ${ }^{2 .}$ Dewi Octaviana Caisara \\ ${ }^{1 .}$ Dosen APIKES Imelda, Jalan Bilal Nomor 52 Medan; ${ }^{2}$ Mahasiswa APIKES Imelda \\ E-mail: ${ }^{1 .}$ mmartasimanjuntak@gmail.com
}

\begin{abstract}
ABSTRAK
Kinerja petugas rekam medis adalah suatu hasil kerja secara kualitas dan kuantitas yang dicapai oleh petugas dalam melaksanakan tugasnya sesuai dengan tanggung jawab yang diberikan. Dalam mencapai kinerja yang maksimal diperlukan sistem reward sebagai dorongan atau motivasi seseorang dalam bekerja. Reward adalah insentif positif yang berupa penghargaan, anugerah, dan imbalan akibat hasil kerja yang baik yang dilakukan karyawan. Metode penelitian ini menggunakan deskriptif kuantitatif. Populasi dalam penelitian ini adalah seluruh petugas rekam medis di unit rekam medis Rumah Sakit Umum Pusat Haji Adam Malik Medan, sampel diambil menggunakan teknik total sampling berjumlah 84 petugas. Instrumen penelitian ini menggunakan lembar kuesioner dan dianalisis dengan menggunakan chi squaredengan tingkat signifikan P-value <0,032, bahwa ada hubungan reward dengan kinerja. Hasil Penelitian menunjukkan bahwa sistem penghargaan di Rumah Sakit Haji Adam Malik Medan biasanya disebut rumenerasi, dan hanya diberikan kepada pegawai PNS. Dan dari hasil pengolahan data didapat hasil bahwa petugas yang mendapatkan penghargaan berupa upah atau remunerasi dengan kinerja yang baik 44 orang (52,4\%), dan petugas yang tidak mendapatkan penghargaan sebanyak 40 orang (47,6. Disarankan kepada direktur agar memberi penghargaan secara adil dan merata sesuai dengan kinerja petugas.
\end{abstract}

Kata Kunci: Penghargaan (Reward), Kinerja Petugas, Rekam Medis.

\section{PENDAHULUAN}

Hakikat dasar dari rumah sakit adalah pemenuhan kebutuhan dan tuntutan pasien yang mengharapkan penyelesaian masalah kesehatannya pada rumah sakit. Pasien memandang bahwa hanya rumah sakit yang mampu memberikan pelayanan medis sebagai upaya penyembuhan dan pemulihan atas rasa sakit yang dideritanya. Pasien mengharapkan pelayanan yang siap, cepat, tanggap dan nyaman terhadap keluhan penyakit pasien.

Rumah sakit merupakan sarana pelayanan kesehatan yang mutlak dibutuhkan oleh segenap lapisan masyarakat dalam upaya peningkatan derajat kesehatan baik individu maupun masyarakat secara keseluruhan. Untuk memenuhi kebutuhan tersebut maka rumah sakit dituntut untuk memberikan pelayanan yang memadai dan memuaskan. Oleh karena itu, rumah sakit harus mampu meningkatkan kualitas pelayanannya, termasuk diantaranya peningkatan kualitas pendokumentasian rekam medis (Pamungkas, dkk, 2010).

Salah satu parameter untuk menentukan mutu pelayanan kesehatan di rumah sakit adalah data atau informasi dari rekam medis yang baik dan lengkap. Seiring dengan pesatnya perkembangan teknologi pelayanan kesehatan, maka hampir mustahil sebuah institusi rumah sakit berjalan tanpa adanya instalasi rekam medis.

Menurut Peraturan Menteri Kesehatan RI No 55 Tahun 2013, bahwa rekam medis adalah berkas yang berisi catatan dan dokumen tentang identitas pasien, pemeriksaan, pengobatan, tindakan dan pelayanan lain kepada pasien di sarana 
pelayanan kesehatan. Rekam medis bersifat rahasia karena menyangkut data pribadi seseorang dengan penyakit yang diderita, riwayat penyakit dan diagnosis lainnya. Mengingat begitu pentingnya isi serta peranan rekam medis, seharusnya setiap rumah sakit dan institusi pelayanan kesehatan menyimpan, menyusun dan merawat rekam medis dengan baik serta menjaga keamanannya dari kerusakan dan penyalahgunaan oleh pihak-pihak tertentu yang tidak berhak, dan juga menyediakan berkas rekam medis tersebut setiap kali dibutuhkan.

Faktor sumber daya manusia disini sangat erat kaitannya dengan kualitas pendokumentasian rekam medis yang efektif dan efisien, dimana jika faktor sumber daya manusia tidak dikelola dengan baik tentunya akan mempengaruhi tingkat kepuasan pasien. Sumber daya manusia merupakan satu-satunya sumber daya yang memiliki akal, perasaan, keinginan, keterampilan, pengetahuan, dorongan, daya, dan karya, jika tanpa SDM akan sulit bagi suatu organisasi untuk mencapai tujuannya (Edy Sutrisno, 2016).

Manajemen sumber daya manusia merupakan program, aktivitas untuk mendapatkan, mengembangkan, memelihara dan mendayagunakan sumber daya manusia untuk mendukung perusahaan mencapai tujuannya. Dalam mencapai tujuan rumah sakit, dibutuhkan sumber daya manusia (pegawai) yang berkualitas. Kualitas kinerja pegawai rumah sakit harus selalu dipelihara dan ditingkatkan, salah satu caranya dengan penerapan reward.

Menurut Sule dan Saefullah (2005) reward atau kompensasi yang diberikan organisasi kepada individu adalah : upah, kepastian dan keamanan kerja, benefit, peluang karir, status dan peluang promosi.

Kinerja organisasi sangat ditentukan oleh unsur pegawai karena dalam mengukur kinerja suatu organisasi diukur dalam tampilan kerja dari pegawai. Pengertian kinerja menurut Mangkunegara(2006) adalah hasil kerja secara kualitas dan kuantitas yang dicapai oleh seorang pegawai dalam melaksanakan tugasnya sesuai dengan tanggung jawab yang diberikan.
Harapan atas profesionalisme dan kinerja yang baik dari seorang pegawai rumah sakit tak terlepas dari bagaimana suatu rumah sakit mampu mengelola serta memberikan penghargaan terhadap pegawai yang dimiliki. Karena kualitas sumber daya manusia merupakan gambaran terhadap perlakuan yang diberikan suatu rumah sakit kepada pegawai, baik langsung maupun tidak langsung memiliki pengaruh terhadap perjalanan rumah sakit tersebut guna meningkatkan kinerja rumah sakit kearah yang lebih baik.

Berdasarkan survey yang dilakukan pada bulan Juni di Rumah Sakit Pusat H. Adam Malik Medan dengan wawancara salah satu petugas rekam medis, terdapat penghargaan atau reward yang berasal dari pemerintah dan diberikan kepada petugas rekam medis yang sudah menjadi pegawai negeri sipil (PNS) yang biasa disebut remunerasi atau tunjangan kinerja sedangkan pegawai yang masih honorer tidak diberikan remunerasi tersebut. Reward tersebut diberikan berdasarkan pendidikan dan lama kerja. Peneliti ingin mengetahui adakah hubungan dari penghargaan terhadap kinerja petugas rekam medis.

Berdasarkan latar belakang diatas penulis tertarik melakukan penelitian dengan judul "Hubungan Pemberian Penghargaan (Reward) Dengan Kinerja Petugas Rekam Medis Di Rumah Sakit Pusat H. Adam Malik Medan Tahun 2018.

\section{Perumusan Masalah}

Berdasarkan latar belakang masalah yang telah dikemukakan di atas, maka masalah penelitian dapat diidentifikasi sebagai berikut:

1. Bagaimana sistem pemberian penghargaan (reward) di RSUP H.Adam Malik Medan tahun 2018?

2. Adakah hubungan antara penghargaan (reward) dengan peningkatan kinerja petugas rekam medis di Rumah Sakit Umum Pusat H.Adam Malik Medan Tahun 2018?

\section{Tujuan Penelitian}

Untuk mengetahui hubungan penghargaan (reward) dapat mempengaruhi 
atau meningkatkan kinerja petugas rekam medis di Rumah Sakit Umum Pusat H.Adam Malik Medan.

\section{Manfaat}

1. Bagi Rumah Sakit Sebagai bahan masukan dan pertimbangan dalam manajemen perencanaan an kinerja petugas rekam medis di masa yang akan datang.

2. Bagi Institusi Sebagai bahan perbandingan atau referensi pada studi atau penelitian di masa yang akan dating.

3. Bagi Peneliti Sebagai bahan perbandingan antara ilmu yang diperoleh selama pendidikan dengan kenyataan di lapangan atau tempat penelitian, sealigus untuk menambah pemahaman dan pengetahuan tentang kinerja petugas rekam medis

\section{METODE}

\section{Jenis Penelitian}

Jenis penelitian yang digunakan dalam pembuatan karya tulis ilmiah ini adalah penelitian deskriptif kuantitatif dengan pendekatan cross sectional untuk mengetahui hubungan pemberian penghargaan dengan kinerja petugas rekam medis di Rumah Sakit Umum Pusat Haji Adam Malik Medan Tahun 2018.

Metode penelitian ini menggunakan observasi dan kuesioner. Observasi adalah pengamatan langsung yang dapat dilakukan melalui penglihatan, penciuman, pendengaran, peraba dan pengecap dan dapat dilakukan dengan tes, kuesioner, rekaman gambar, rekaman suara. Kuesioner adalah sejumlah pertanyaan tertulis yang digunakan untuk memperoleh informasi dari responden dalam arti laporan tentang pribadinya, atau hal-hal yang ia ketahui (Arikunto, 2010).

\section{Waktu Penelitian}

Waktu penelitian dilaksanakan mulai bulan September 2017- Januari 2018.

\section{Tempat Penelitian}

Penelitian ini dilakukan di RSUP H.Adam Malik Medan yang berlokasi di Jl. Bunga Lau No.17 Medan, Sumatera Utara, Indonesia. Alasan peneliti memilih lokasi ini adalah selain lokasinya terjangkau, juga peneliti sebelumnya telah melakukan wawancara pada petugas rekam medis dan hasilnya mengatakan bahwa terdapat penghargaan yang diberikan kepada petugas rekam medis.

\section{Populasi}

Populasi adalah keseluruhan objek penelitian atau objek yang diteliti (Notoatmodjo, 2012). Populasi dalam penelitian ini adalah seluruh petugas rekam medis di Rumah Sakit Umum Pusat Haji Adam Malik Medan sebanyak 84 (delapan puluh empat) orang.

\section{Sampel}

Sampel dalam penelitian ini adalah petugas rekam medis di Rumah Sakit Umum Pusat Haji Adam Malik berjumlah 84 orang.

\section{Teknik Sampling}

Teknik samping yang digunakan dalam penelitian ini adalah teknik total sampling. Pengambilan sampel secara total dilakukan dengan cara menetapkan jumlah populasi sebagai jumlah sampel (Notoatmodjo, 2012).

\section{Variabel Penelitian}

Variabel adalah objek penelitian yang menjadi titik perhatian suatu penelitian (Arikunto, 2010). Adapun variabel-variabel yang akan diamati oleh peneliti yaitu:

1. Variabel Independent (variabel bebas) dalam penelitian ini yaitu reward terdiri dari insentif, kenaikan pangkat, pendidikan \& pelatihan, dan motivasi.

2. Variabel Dependent (variabel terikat) dalam penelitian ini yaitu kinerja petugas rekam medis.

\section{Definisi Operasional}

Definisi operasional membatasi ruang lingkup atau pengertian variabel-variabel yang diamati/diteliti sehingga bermanfaat untuk mengarahkan kepada pengukuran atau 
pengamatanterhadap variabel-variabel yang bersangkutan serta pengembangan instrumen /alat ukur (Notoatmodjo, 2012).

1. Insentif adalah penghargaan positif yang diberikan rumah sakit sebagai motivasi bagi pegawai agar lebih giat dalam bekerja.

2. Kenaikan Pangkat adalah salah satu bentuk penghargaan yang patut diberikan kepada pegawai yang memiliki produktivitas sangat tinggi.

3. Pendidikan/ Pelatihan adalah salah satu hal yang besar pengaruhnya terhadap peningkatan produktivitas kerja pegawai. Semakin tinggi pendidikan pegawai, semakin besar ia dapat bekerja dengan efektif dan efisien sehingga mampu untuk meningkatkan prestasinya ke jenjang yang lebih baik dan lebih tinggi.

4. Motivasi adalah hal sederhana yang dapat mempengaruhi kinerja pegawai dalam rumah sakit.

5. Kinerja adalah hasil kerja yang dicapai oleh pegawai sesuai dengan tanggung jawabnya masing-masing.

\section{Instrumen Penelitian}

Instrumen penelitian adalah alat atau fasilitas yang digunakan peneliti dalam mengumpulkan data mengenai variabelvariabel yang akan diamati (Arikunto, 2010). Jenis instrumen penelitian ini menggunakan kuesioner. Kuesioner adalah sejumlah pertanyaan tertulis untuk memperoleh informasi dari responden dalam arti laporan tentang pribadinya atau hal-hal yang ia ketahui.

\section{Cara Pengumpulan Data}

Data primer adalah data yang diperoleh peneliti secara langsung dari subjek penelitian. Data primer pada penelitian ini diperoleh dari hasil observasi atau wawancara kepada petugas rekam medis dan juga dengan cara membagikan kuesioner kepada petugas rekam medis tentang hubungan pemberian penghargaan dengan kinerja petugas.

Data sekunder adalah data yang diperoleh peneliti dari pihak lain, tidak langsung diperoleh oleh peneliti dari subjek penelitian. Data sekunder pada penelitian ini diperoleh dari dokumen atau data di RSUP H.Adam Malik yang terdiri dari profil rumah sakit, jumlah dan pendidikan petugas rekam medis di instalasi rekam medis.

\section{Teknik Pengolahan Data}

Beberapa langkah yang dilakukan dalam pengolahan data terdiri dari:

1. Collecting Data

Mengumpulkan data dari hasil observasi dan kuesioner responden.

2. Editing Data

Mengoreksi jawaban yang telah didapat dari responden, apabila terdapat data yang kurang lengkap atau salah segera diperbaiki.

3. Coding Data

Melakukan klasifikasi atau pengkodean untuk beberapa variabel yang akan diteliti agar mempermudah peneliti dalam menganalisa data.

4. Penyajian Data

Menguraikan data yang telah dikumpulkan kedalam bentuk kalimat sehingga mudah dipahami.

\section{Teknik Analisis Data}

Analisa data dalam penelitian ini menggunakan uji SPSS dengan jumlah sampel 84 untuk menganalisa hubungan pemberian penghargaan (reward) dengan kinerja petugas rekam medis di RSUP H.Adam Malik Medan tahun 2017.

Data akan dianalisis dengan menggunakan statistik deskriptif yaitu teknik analisa data yang menggambarkan situasi objek penelitian apa adanya sesuai dengan data yang terkumpul. Analisis pada penelitian ini dilakukan dengan bantuan komputer menggunakan program special product for science solution (SPSS) dan teknik analisis data menggunakan rumus sebagai berikut:

\section{HASIL}

Setelah melakukan penelitian tentang Hubungan Pemberian Penghargaan (Reward) Dengan Kinerja Petugas Rekam Medis di Rumah Sakit Umum Pusat Haji Adam Malik Medan pada bulan Juni sampai 
bulan Januari 2018 dengan responden sebanyak 84 orang. Maka hasil yang diperoleh peneliti adalah sebagai berikut:

\section{Karakteristik Responden}

Tabel 1. Distribusi Frekuensi Hubungan Penghargaan (Reward) dengan Kinerja Petugas Rekam Medis Berdasarkan Jenis Kelamin

\begin{tabular}{cccc}
\hline No & Jenis Kelamin & Frekuensi & \% \\
\hline 1 & Laki-laki & 17 & 20,2 \\
\hline 2 & Perempuan & 67 & 79,8 \\
\hline Total & & $\mathbf{8 4}$ & $\mathbf{1 0 0}$ \\
\hline
\end{tabular}

Dari tabel di atas dapat dilihat bahwa responden yang berjenenis kelamin Lakilaki sebanyak 17 orang $(20,2 \%)$ dan yang berjenis kelamin perempuan sebanyak 67 orang $(79,8 \%)$.

Tabel 2. Distribusi Frekuensi Hubungan Penghargaan (Reward) dengan Kinerja Petugas Rekam Medis Berdasarkan Umur

\begin{tabular}{cccc}
\hline No & Umur & Frekuensi & \% \\
\hline 1 & $20-25$ tahun & 13 & 15,5 \\
\hline 2 & $26-30$ tahun & 25 & 29,8 \\
\hline 3 & $31-35$ tahun & 7 & 8,3 \\
\hline 4 & $36-40$ tahun & 7 & 8,3 \\
\hline 5 & $>40$ tahun & 32 & 38,1 \\
\hline Total & & $\mathbf{8 4}$ & $\mathbf{1 0 0}$ \\
\hline
\end{tabular}

Dari tabel di atas dapat dilihat bahwa responden yang memiliki usia 20-25 tahun sebanyak 13 orang (15,5\%), usia 26-30 tahun sebanyak 25 orang $(29,8 \%)$, usia 31 35 sebanyak 7 orang $(8,3 \%)$, usia $36-40$ tahun sebanyak 7 orang $(8,3 \%)$, dan usia $>40$ sebanyak 32 orang $(38,1 \%)$.

Tabel 3. Distribusi Frekuensi Hubungan Penghargaan (Reward) dengan Kinerja Petugas Rekam Medis Berdasarkan Pendidikan

\begin{tabular}{cccc}
\hline No & Pendidikan & Frekuensi & \% \\
\hline 1 & SMA & 27 & 32,1 \\
\hline 2 & D-III & 44 & 52,4 \\
\hline 3 & S-1 & 13 & 15,5 \\
\hline Total & & $\mathbf{8 4}$ & $\mathbf{1 0 0}$ \\
\hline
\end{tabular}

Dari tabel di atas dapat dilihat bahwa responden yang berpendidikan SMA sebanyak 27 orang $(32,1 \%)$, yang berpendidikan D-III sebanyak 44 orang $(52,4 \%)$, dan yang berpendidikan S-1 sebanyak 13 orang $(15,5 \%)$.

Tabel 4. Distribusi Frekuensi Hubungan Penghargaan (Reward) dengan Kinerja Petugas Rekam Medis Berdasarkan Lama Kerja

\begin{tabular}{cccc}
\hline No & Lama Kerja & Frekuensi & \% \\
\hline 1 & $1-5$ tahun & 29 & 34,5 \\
\hline 2 & $6-10$ tahun & 15 & 17,9 \\
\hline 3 & $11-15$ tahun & 10 & 11,9 \\
\hline 4 & $>15$ tahun & 30 & 35,7 \\
\hline Total & & $\mathbf{8 4}$ & $\mathbf{1 0 0}$ \\
\hline
\end{tabular}

Dari tabel di atas dapat dilihat bahwa responden dengan lama kerja 1-5 tahun sebanyak 29 orang $(34,5 \%)$, lama kerja 6-10 tahun sebanyak 15 orang (17,9\%), lama kerja 11-15 tahun sebanyak 10 orang $(11,9 \%)$, lama kerja $>15$ tahun sebanyak 30 orang $(35,7 \%)$.

Tabel 5. Distribusi Frekuensi Hubungan Reward dengan Kinerja Petugas Rekam Medis di Rumah Sakit Umum Pusat H.Adam Malik Medan 2017

\begin{tabular}{lcccccc}
\hline \multirow{2}{*}{ Reward } & \multicolumn{9}{c}{ Kinerja } & \multirow{2}{*}{ Total } & p-value \\
\cline { 2 - 5 } & Baik & \% & Cukup & \% & & \\
\hline Ada & 36 & 42,9 & 4 & 4,8 & $40(47,6 \%)$ & 0,032 \\
\hline Tidak ada & 44 & 52,4 & 0 & 0 & $44(52,4 \%)$ & \\
\hline Total & $\mathbf{8 0}$ & & $\mathbf{4}$ & & $\mathbf{8 4}(\mathbf{1 0 0} \%)$ \\
\hline
\end{tabular}

\section{Hasil Observasi}

Dari hasil wawancara dengan salah satu petugas rekam medis didapat hasil bahwa ada tunjangan kinerja yang biasa disebut remunerasi. Remunerasi tersebut diberikan kepada pegawai PNS saja. Untuk mendapatkan remunerasi tersebut ada indikator kinerja yang dinilai dan harus dicapai sesuai target yang ditentukan setiap bulannya, antara lain:

1. Kuantitas seperti contoh registrasi pasien baru gawat darurat dengan target 100 berkas.

2. Kualitas, dapat diukur dengan penilaian sebagai contoh tingkat kepuasan pelanggan internal dan eksternal 
3. Perilaku dapat diukur dengan kepatuhan, sikap perilaku, kerjasama, kehandalan, keberadaan, inisiatif.

4. Kegiatan Tambahan

\section{PEMBAHASAN}

Berdasarkan tabel hasil distribusi frekuensi reward dengan kinerja petugas rekam medis dari 84 responden menunjukkan bahwa yang mendapatkan penghargaan (reward) sebanyak 44 responden $(52,4 \%)$ dan yang tidak mendapatkan penghargaan sebanyak 40 responden $(47,6 \%)$. Petugas yang tidak mendapat upah atau remunerasi tersebut adalah petugas non PNS.

Berdasarkan tabel 4.5 dapat dilihat bahwa nilai $\mathrm{P}$-value $\leq 0.032$ yang berarti $\mathrm{Ha}$ diterima ada hubungan penghargaan (reward) dengan kinerja petugas rekam medis. Pemberian penghargaan adalah salah satu cara untuk memotivasi petugas untuk bekerja dengan baik sesuai dengan tanggung jawabnya bahkan melebihi target pekerjaan yang telat ditetapkan rumah sakit.

Penghargaan (reward) terutama gaji dan upah termasuk sebagai suatu syarat untuk memenuhi kebutuhan dasar. Apabila kebutuhan dasar terpenuhi, maka manusia akan mempunyaidorongan untuk berusaha, mungkin dengan bekerja keras untuk memperolehnya.

\section{KESIMPULAN}

Berdasarkan hasil penelitian yang diuraikan pada bab IV, didapat kesimpulan :

1. Terdapat system penghargaan (reward) di Rumah Sakit Umum Pusat H. Adam Malik Medan yang biasa disebut Remunerasi. Remunerasi tersebut diberikan kepada pegawai yang sudah PNS. Dan untuk mendapatkan remunerasi tersebut ada indicator penilaian kinerja yang harus dicapai sesuai target.

2. Petugas yang mendapatkan penghargaan (reward) sebanyak 44 orang $(52,4 \%)$ dan yang tidak mendapatkan penghargaan sebanyak 40 orang $(47,6 \%)$. Petugas yang tidak mendapat penghargaan adalah petugas non PNS.

3. Berdasarkan tabel 4.5 dapat dilihat bahwa nilai P-value $\leq 0.032$ yang berarti ada hubungan penghargaan (reward) dengan kinerja petugas rekam medis.

\section{SARAN}

Berdasarkan kesimpulan maka dapat diberikan saran : Kepada pihak rumah sakit agar memberikan penghargaan kepada pegawai non PNS juga, karena jika hasil kerjanya memuaskan patut mendapatkan penghargaan.

\section{DAFTAR PUSTAKA}

Aditama, YT. (2007). Manajemen Administrasi Rumah Sakit. Edisi ke-2. Jakarta: UI-Press.

Arikunto, S. (2010). Prosedur Penelitian Suatu Pendekatan Praktik. Jakarta: Rineka Cipta.

Budi, Citra, Savitri. (2011). Manajemen Unit Kerja Rekam Medis. Yogyakarta: Quantum Sinergis Media.

Departemen Kesehatan Republik Indonesia. (2006). Pedoman Penyelenggaraan dan Prosedur Rekam Medis Rumah Sakit di Indoensia. Revisi ke-2. Jakarta: Depkes RI.

Hamzah. (2007). Teori Motivasi dan Pengukurannya Analisis di Bidang Pendidikan. Jakarta: Bumi Aksara.

Hatta, GR. 2010. Pedoman Manajemen Informasi Kesehatan di Sarana Pelayanan Kesehatan (Edisi Revisi). Jakarta:UI-press.

Mangkunegara. (2006). Evaluasi Kinerja Sumber Daya Manusia. Jakarta: Refika Aditama.

Notoadmodjo. (2012). Metodologi Penelitian Kesehatan. Jakarta: Rineka Cipta.

Nurmiyati, Eni. (2011). Hubungan Pemberian Reward dan Punishment dengan Kinerja Karyawan pada BPRS Harta Insan Karimah. http://repository.uinjkt.ac.id.pdf. 
Diakses tanggal 19 Mei 2017 jam 21.00 WIB.

Peraturan Menteri Kesehatan PerMenKes RI No.269/MENKES/PER/III/2008 tentang Rekam Medis. Jakarta.

Pormiki. (2015). Definisi dan Isi Rekam Medis Sesuai Permenkes 269 Tahun 2008. Diakses: 10 April 2017 Jam 22.04 WIB.

https://pormiki.or.id/definisi-dan-isirekam-medis-sesuai-permenkes-no269menkesperiii2008 html.

Purnama, Vici. (2015). Pengaruh Reward dan Punishment terhadap Kinerja
Karyawan PT.Kereta Api Indonesia Persero DAOP 8 Surabaya. http://library.uwp.ac.id.pdf. Diakses tanggal 18 Mei 2017 jam 19.00 WIB.

Sule dan Saefullah, K. (2005). Pengantar Manajemen. Jakarta: Prenada Media.

Sutrisno, Edy. (2016). Manajemen Sumber Daya Manusia. Jakarta: Kencana Pernada Media Group.

Wibowo. (2014). Manajemen Kinerja. Jakarta: Raja Grafindo Persada. 